\title{
IMPROVING ENGLISH SPEAKING SKILL THROUGH \\ "ROLE-PLAY"TECHNIQUE
}

\author{
Ikhwan Muslim \\ STIBA-IEC Bekasi \\ ikhwanmuslim91@gmail.com
}

\begin{abstract}
The Purpose of this study is to get the empirical knowledge of the Role-play technique to improve speaking ability, to know if the role-play effective in teaching speaking, to find the answer if the role is effective to improve English speaking ability. The technique of the research is qualitative. The data from field was done through observation in the classroom. Here the writer directly taught the students and observed students' activities in speaking class. The writer explains the finding and gives some samples of role-play technique, activities in teaching and how to teach speaking through role-play technique.
\end{abstract}

\section{Keywords: speaking skill, role play, techniques}

\section{A. INTRODUCTION}

\section{Background}

Nowadays, many English courses are available anywhere in regions. People who want to improve their English speaking ability are provided by so many facilities. The big number of members in the public courses is one the proof that teenagers or even children are having a big desire to be able to speak English. However, though so many English courses are provided it doesn't means that people will directly have any confidentiality to join and speak.

Actually, English materials in classrooms do not meet their needs in learning English since students still seek for other places to learn English more. Most of students learning English in the classroom are always passively involved in its learning process. 
Many factors can cause the problem of the students' speaking skills namely the students' interest, the material, and the media among others including the technique in teaching English. Many techniques can be applied including role play because many research findings say that this technique is effective to use in teaching speaking.

Role-play is an alternative to using the English language as much as possible. When compared with the method of discussion that sometimes saturate and more dominant in the discussion in general that the smart students, while other students just silent. In the "Role-Play" every student is given the opportunity to speak with a more lively atmosphere for any student interested in playing the role not as the discussion was dominated by good students in speaking English.

\section{The Objective}

Based on the problem above, the objective of this study is to get the understanding about how to teach speaking through role-play technique and the effectiveness of role-play for teaching speaking.

\section{Theoretical Framework}

Theodore Huebner said in his book "Speaking is a skill used by someone in communication in daily life whether at school or outside. The skill is acquired by much repetition; it is primarily a neuromuscular and not an intellectual process. It consists of competence in sending a receiving message.

According to Chomsky, (in Brown, 2008: 33) Speaking skill is the capability to other the articulation to express, to state or deliver though, opinion and wish to the other person. The People who know a language called as speaker of the language. Speaking includes all other kinds of knowing and many activities of foreign language learners are primary interest to speak.

\subsection{Teaching Speaking}


Jeremy Harmer suggested on his book, there are some many classroom-speaking activities that are currently in use in communicative class.

\section{a. Acting from Script}

The teacher can ask the students to act out scenes from plats and or their course books, sometimes filming the result. Students will often act out dialogues they have written themselves. This frequently involves them in coming out to the front of the class.

\section{b. Communication Games}

Games which are design to provoke communication between students frequently depend on an information gap, so that one student has to talk to a partner in order to solve a puzzle, draw a picture (describe and draw), put things in the right order (describe and arrange), or find similarities and differences between pictures.

\section{c. Discussion}

One of the reason that discussions fail (when they do) is that students are reluctant to give an opinion in front of the whole class, particularly if they cannot think of anything to say and are not, anyway, confident of the language they might use to say it. Many students feel extremely exposed in discussion situations.

\section{d. Prepared Talks}

A popular kind of activity is the prepared talk where students make presentation on a topic of their own choice. Such talks are not designed for informal spontaneous conversation; because they are prepared, they are more writing-like than this. However, if possible, students should speak from notes than from a script.

\section{e. Questionnaires}

Questionnaires are useful because, by being pre-planned, they ensure that both questioner and respondent have something to say to each other. Depending upon how tightly designed they are, they may well encourage the natural use of certain repetitive language pattern-and thus be situated in the middle of our communication continuum. 


\section{f. Problem solving}

The material is used in this technique giving the students to work in pairs or groups. They share their problem, opinion and feeling. In this case the teacher as the bridge to communicate among the participants. Then, the students give a question and answer each other. This communication will help the students practicing and expressing their ideas in spoken language.

\section{g. Role-play}

A popular way of the aspect of speaking activities is to use simulations and role plays. This is where students pretend that they are in a different situation, either as themselves or playing the role of someone is quite different. We could ask them to be guest at some parties and go there as different characters. They could, as themselves, pretend to be at an airport trying to check luggage, or either as themselves or another character take part in a television program. In all these cases the students are using language in order to participate in the activity rather than other way round! Some students find it very comfortable to use language in a simulated environment, playing the role of someone else -it allows them to experiment freely to be another people.

\section{Methodology}

This study aimed to get the understanding about the students' activities in teaching speaking using role-play. The method used in this research is qualitative method to describe the process of teaching speaking using role-play.

\section{B. RESULT AND DISCUSSION}

\section{The advantages of using role play technique}

Based on the result of the data, it is proven that the students skill of speaking taught by using role play is better. It means that the use of role play in teaching speaking is quite effective. Another reason based on the students responses most students find that role play is enjoyable. This reason leads to 
better attention in learning and stimulate them to participate in role play activities, also role play is very helpful for the learners to improve their English speaking ability, it shown that the students skill of speaking have improvement after taught by using role play.

\section{CONCLUSION}

Based on the research, the writer concludes that:

From the result of the analysis of the research, it is proven that the students of speaking taught by using role play is better. This result has answered the research question that the use of role play in teaching speaking is quite effective.

a. The use of role play makes the speaking and learning activity more enjoyable and interesting. It is because role play helps the shy students by providing a mask, where students with difficulty in conversation are liberated. In addition, it is fun and most students will agree that enjoyment leads to better learning.

b. In role play, the world of the classroom is broadened to include the outside world. This offers a much wider range of language opportunities. So, the students can be anyone and in any situation they wish.

c. The use of role play makes the class more active and alive. Students are willing to participate without any forces from the teacher.

d. The use of role play makes the students more motivated in learning and easier to grasp the lesson.

\section{BIBLIOGRAPHY}

Brown, H. Douglas. 1994. Teaching by Principle an Interactive an Approach to Language Teaching. Oxford University Press.(x) 
Brown and Yule.Teaching the Spoken language. (New York, Cambridge University Press 1999)(0)

Byrne, Donn.1986. Teaching Oral English: Longman Handbooks for English Teacher. Singapore: Longman Group.(0)

Crookal, D, and R.L. Oxford. 1990. Simulation, Gaming, Language Learning. New York: Newbury House. (x)

Doff, Adrian. 1988. Teach English: A Training Course for Teachers Trainer's Handbooks. The British Council: Cambridge University Press Inc.(0)

Harmer, Jeremy. 2001. The Practice of English Language Teaching. England. Pearson education limited Thomas Gordon. 1997. Teacher Effectiveness Training . Jakarta: Gramedia.(0)

House, Susan. 1997. An Introduction to Teaching English to Children. Richmond Publishing. $(\mathrm{x})$

Huebner, Theodore. 1960. Audio Visual Technique in Teaching foreign Language. New York. Cambridge University Press. (x)

Kathlen M. Bailey and Nunan. Practical English Language Teaching: Speaking,(New York, The McGraw Hill Companies, 2005).(x)

Krish, Pramela. July 2001. "A Role Play Activity with Distance Learners in an English Language Classroom", The Internet TESL Journal. Vol. VII, No. 7(0)

Ladousse, Gillian Porter. 1995. Role Play: Resources Book for the Teacher Series. New York.

Oxford University Press.(0)

Rohaniah, 2008. The Effeect of Communicative Approach Toward Students' Speaking Ability, For Beginning Level of The First Year Students of MTs. NW Korleko in the School Year 2007-2008. Thesis S-1 STKIP Hamzanwadi at Selong. Unpublished.

http://wirmanvalkinz.blogspot.com/2012/12/kumpulan-skripsi-bahasainggris-effect.html(0)

Tompkins, Patricia K. 1998. "Role Playing/Simulation”, The Internet TESL Journal. Vol.IV. No.8 (o) 